\title{
Parents' Experiences and Acceptance Factors of AAC Intervention for Children with Complex Communication Needs
}

\author{
HyunJu Park \\ Division of Speech-Language Pathology, Gachon University, Seongnam, Korea
}

Correspondence: HyunJu Park, PhD

Division of Speech-Language Pathology, Gachon

University, 1342 Seongnam-daero, Sujeong-gu,

Seongnam 13120, Korea

Tel: + 82-31-750-8881

Fax: +82-31-750-8837

E-mail: phj8747@gachon.ac.kr

Received: April 5, 2020

Revised: May 9, 2020

Accepted: May 9, 2020

\begin{abstract}
Objectives: This study examined the experiences of parents of children with complex communication needs who received AAC interventions. It sought to explore the factors that facilitated parent acceptance of the AAC intervention to identify explicit approaches for encouraging acceptance and implementation. Methods: The study was conducted as a qualitative research. 12 parents of children with complex communication needs were individually interviewed in-depth. The interviews were all transcribed and then analyzed using the constant comparative method. Results: A total of 7 themes with 24 associated sub-themes were identified regarding parents' experiences of AAC intervention; namely increase in satisfaction with communication intervention, awareness of need for early intervention, change in expectations for child's quality of life, increase of competence in parenting, need for improvement of AAC systems, demand for increased access to AAC, and continued expectations of speech production. The factors that affected the parents' acceptance of AAC interventions were categorized into parent perception and propensity and environmental support, with 7 associated sub-themes. Conclusion: Based on the results, the study discussed the factors and means of support that must be considered for the early acceptance and sustained implementation of AAC intervention for children with complex communication needs. Continual cooperation and efforts on the part of stakeholders is necessary to further encourage $A A C$ intervention for children with complex communication needs.
\end{abstract}

Keywords: Augmentative and alternative communication, Children with complex communication needs, AAC intervention, Acceptance factors, Qualitative research
Complex communication needs $(\mathrm{CCN})$ is the recommended term for severe communication impairments and occurs when the current means of communication cannot meet everyday communication needs (Beukelman \& Mirenda, 2013; Justice \& Redle, 2013). Children with CCN due to developmental disorders such as autism spectrum disorder, cerebral palsy, or intellectual disability can benefit in various aspects from augmentative and alternative communication (AAC) intervention (Beukelman \& Mirenda, 2013; Drager, Light, \& McNaughton, 2010; Iacono, 2004). For example, Drager et al. (2010) asserted that children with CCN can through AAC intervention develop functional communication, cognitive/conceptual, and literacy skills, increase their levels of educational access and social participation, and improve their overall quality of life.

Despite the benefits of AAC intervention for children with CCN, when introduced to stakeholders it is not always readily accepted and sustained. In this regard, it is necessary to consider the research of Johnson, Inglebret, Jones, \& Ray (2006). These researchers surveyed 275 speech-language pathologists (SLPs) who were active members of the AAC sub-group in the American Speech-Language-Hearing Association (ASHA) on their respective clients' usage of AAC systems. According to the results of their study, the 
average rate of successful usage sustained for at least a year of highor low-tech AAC systems introduced by SLPs was 39.35\%. These results indicate that more than $60 \%$ of clients ceased usage of or otherwise underutilized AAC systems introduced to them.

Existing research suggests that there are limits to the application of conventional communication intervention toward children with $\mathrm{CCN}$, and that the provision of AAC intervention early on is critical to the achievement of successful and functional outcomes (Beukelman \& Mirenda, 2013; Drager et al., 2010; Smith \& Hustad, 2015). Therefore, it is necessary to strengthen opportunities for and eliminate barriers to the provision of early AAC intervention for children with CCN. Under these demands, recent studies have focused on the AAC experiences of parents, the most important stakeholders with regard to the adoption and implementation of AAC intervention for children with $\mathrm{CCN}$, exploring the factors influencing their acceptance or rejection of AAC systems (Moorcroft, Scarinci, \& Meyer, 2019a, 2019b). Moorcroft et al. (2019a) conducted a qualitative study of 12 parents of children who refused or abandoned AAC systems and reported their results as a thematic analysis. The factors behind these parents' rejection and abandonment of AAC systems for their children included a lack of emotional readiness and resilience, the increase in work outside of routine parenting, the child's disuse of AAC for communicative purposes, and dissatisfaction with AAC systems. Moorcroft et al. (2019b) also conducted a qualitative study of 16 SLPs who have experienced parents' acceptance, rejection, or abandonment of AAC systems for their children. The results of the study indicate that the factors affecting the acceptance of AAC for children with CCN included themes such as the parents' views on their children and on AAC intervention, parental support, the nature of AAC systems, and services provided by the SLP. Based on the results of the study, the researchers concluded that a comprehensive consideration of not only the child with CCN but the parents, AAC systems, and the competence of the SLP as well is necessary for the adoption of AAC systems.

Korean research regarding AAC for children with CCN is mainly focused on examining the effects of the intervention or surveying the perceptions of key stakeholders. Studies providing AAC intervention to children with CCN and examining the effects report positive results such as advancement of communicative com- petence, improvement in vocabulary, sentence formation and reading skills, and reduction of problematic behaviors (Jung \& Han, 2012; Kim \& Park, 2012; Kim \& Yun, 2015; Pae \& Chae, 2017; Yang \& Han, 2019). Additionally, studies surveying perceptions regarding AAC intervention have targeted key stakeholders such as parents, SLPs, and special education teachers (Cho \& Kang, 2003; Kim \& Park, 2012; Kim, Song, \& Choi, 2013; Lim, Park, \& Ku, 2013; Oh, 2018; Shin \& Lee, 2016). According Cho and Kang's survey (2003) of 116 special education teachers' perceptions of the application of AAC systems to children with CCN, the most significant obstacle to AAC intervention is a lack of parental understanding, and that parents tend to reject AAC intervention especially due to the perception that AAC implementation will hinder their children's verbal development. Furthermore, Kim et al. (2013)'s survey of 148 SLPs reported that the main factor influencing the effect of AAC intervention was insufficient parental cooperation, and that the most significant reason for parents' rejection of AAC was hope for their child's oral communication.

The perception of AAC by parents of children with $\mathrm{CCN}$ can be found in Shin \& Lee (2016). Of the 112 participating parents, only 6 (5.4\%) were utilizing AAC intervention at the time of the study. Furthermore, when the remaining 106 were asked if they would accept AAC if introduced to it, nearly half of the participants (48.9\%) responded that they would take it under consideration. With the inclusion of those parents who expressed enthusiastic assent, $34.8 \%$ of the participants responded that they would accept AAC intervention, while $11.6 \%$ responded that they would not. A total of 16 participants (14.3\%) had discontinued usage of AAC, and the most common reason given for dropout was that AAC was not generalized for environments outside of the therapy room. Parents also responded that their most significant reason for being aware of but not utilizing AAC intervention was their desire for oral communication. These studies all suggest that parents' perceptions and attitudes can have the most impact on their children's acceptance and implementation of AAC intervention. Therefore, if one intends to provide AAC intervention to children with $\mathrm{CCN}$, one must first prioritize paying attention to their parents.

However, the abovementioned studies are all survey researches based on questionnaires. It is difficult to find a Korean study involving parents of children with CCN undergoing AAC interven- 
tion which performs in-depth analysis of their practical experiences and explores their perceptions and needs in detail. Lim et al. (2013) and Jeon \& Kim (2014) are the extent of studies that partially involved parents with AAC intervention experience in their qualitative research. Lim et al. (2013) analyzed experiences and needs regarding AAC intervention services through in-depth individual and focus group interviews with parents of children with developmental disabilities. A total of 10 parents participated in the study, including 7 parents with AAC intervention experience ranging from 3 months to 3 years. As a result of the study, the parents' experiences and demands of AAC were summarized into four categories, one being $\mathrm{AAC}$ intervention experiences and barriers to access, with sub-themes including the communication difficulties of their children, the lack of expert guidance for AAC, insufficient promotion and follow-up, and negative perceptions and a lack of expertise on the part of special education teachers. The researchers regarded the parents as the clientele of AAC intervention services and analyzed their demands, emphasizing the need for client-centered AAC intervention services and delivery systems. Jeon \& Kim (2014) also conducted focus group interviews on 10 special education teachers and 9 parents, exploring their AAC usage experiences and the significance of those experiences after the participants used a smart device AAC application in classroom and home settings with preschool-aged children with CCN. The parents and special education teachers who participated in the study expressed dissatisfaction with the complexity of usage, insufficient content, and high opportunity cost, and utilized AAC systems for the purpose of language education rather than communication; identifying the significance of communication as lying in speech production and regarding $\mathrm{AAC}$ as the last resort for communicating with their children. This study is limited, however, by the fact that it was based on AAC experiences provided during the short period of 1 week. The researchers therefore suggested the need to conduct follow-up research taking a big-picture view of the perspectives of parents and educators who make active use of AAC systems.

As mentioned above, despite abundant evidence supporting the benefits of AAC intervention, there are many negative perceptions surrounding $\mathrm{AAC}$ and few actual users. In particular, the main cause of the low utilization of AAC by children with $\mathrm{CCN}$ can be summed up as the issue of their parents' acceptance (Shin \& Lee, 2016). Parental understanding and cooperation is crucial to the success of AAC intervention for children with CCN. Specific measures should be sought to heighten parental understanding of AAC and to thus help them accept AAC intervention for their children and continue it for as long as needed. Unfortunately, the current paucity of empirical evidence to consult in relation to this matter recommends the urgent collection of relevant data. There exists a need for an examination of the experiences of parents who have utilized AAC systems and intervention and the factors influencing them to continue AAC intervention past a certain point, one not merely limited to a one-time or short-lived fragmentary experience but sustained over a longer term. The words of the experienced are always interesting, concrete, and practical (Beukelman \& Mirenda, 2013; Im \& Park, 2018; Jeon \& Kim, 2014). Although the accumulation of interest and corroborating evidence has led to an upward trend in the number of parents who accept and actively utilize AAC systems for their children with $\mathrm{CCN}$, a study has yet to take place that performs in-depth analysis of their experiences and factors influencing their acceptance.

This study aimed to examine the key content of parents' experiences with AAC through one-on-one in-depth interviews with parents of children with CCN who have received AAC intervention services over a certain period of time. It also seeks to explore the main factors influencing them to accept AAC intervention for their children, in order to gain concrete data for the purpose of providing AAC intervention support for children with CCN. To achieve these objectives, this study was approached as qualitative research with the following established questions: (a) What are the parents' experiences with regard to the AAC intervention of their children with CCN? and (b) What are the factors influencing acceptance of AAC intervention for their children with CCN?

\section{METHODS}

\section{Participants}

This study took the approach of qualitative research due to its aims of conducting one-on-one in-depth interviews with parents of children with CCN who have been receiving AAC intervention for a certain period of time, i.e., a year or more, and thus listening 
to their vivid experiences.

For these purposes, the researcher sought deliberately to obtain individual cases. As such the researcher selected participants according to purposeful sampling and used the snowballing method, one of the representative types of purposeful sampling (Im \& Park, 2018; Merriam, 2009). Participants were first introduced to the researcher through two acquaintances operating a therapy clinic and continued to be introduced until the saturation point was reached (Hughes, Gabel, Goberman, \& Hughes, 2011; Im \& Park, 2018). After the recommenders introduced parents meeting the prerequisites, the researcher made direct contact with them and conducted preliminary interviews over the phone. At this point, the purpose of the study was outlined, and the intention to participate in the study was discussed, and then face-to face interviews were conducted with parents who agreed to participate. Ultimately 12 parents in total participated in the study.

The parents who participated in this study were all mothers in the age range of 35 to 55 years old, with an average age of 43.4 years. In terms of highest level of education achieved, there were 4 high school graduates, 6 college and university graduates, and 2 graduate school graduates. The children numbered 7 male and 5 female, ranging from 5 years and 11 months to 15 years old with an average age of 9 years and 2 months. The diagnoses comprised 4 children with autism spectrum disorder, 4 with brain lesions, 1 with intellectual disability, 1 with language disorder, and 2 with multiple disabilities. The duration of AAC intervention on behalf of their children experienced by the participants ranged from 1 year and 6 months to 7 years, with an average duration of 3 years and 2 months. These participants were identified to have provided both high- and low-tech programs to their children, including AAC dedicated tools such as Kids Voice, tablet PC-based application programs, PECS, and communication boards or books. Information about the participants in the study can be found in Table 1.

\section{Data collection}

\section{Materials}

The material used in this study was a one-page questionnaire divided into background information and interview topics. The questionnaire was produced prior to the interviews. The background information section consisted of demographic questions,
Table 1. Participant Information

\begin{tabular}{lccccc}
\hline Case & Age & $\begin{array}{c}\text { Educa- } \\
\text { tion }\end{array}$ & $\begin{array}{c}\text { Child's } \\
\text { disability }\end{array}$ & $\begin{array}{c}\text { Child's age } \\
\text { (Sex) }\end{array}$ & $\begin{array}{c}\text { AAC intervention period } \\
\text { (Type) }\end{array}$ \\
\hline$\# 1$ & 43 & 16 & ASD & $8 ; 5$ (M) & 2 (high tech, low tech) \\
$\# 2$ & 35 & 16 & ASD & $8 ; 1$ (M) & 2 (high tech, low tech) \\
$\# 3$ & 35 & 12 & ASD, HI & $8 ; 6$ (F) & 2 (high tech, low tech) \\
$\# 4$ & 55 & 16 & BL, ID & $13 ; 3$ (M) & 7 (high tech, low tech) \\
$\# 5$ & 49 & 18 & BL & $15 ; 0$ (F) & 6 (high tech, low tech) \\
$\# 6$ & 40 & 16 & ASD & $8 ; 5$ (M) & 2 (high tech, low tech) \\
$\# 7$ & 41 & 12 & ID & $7 ; 2$ (M) & 3 (high tech, low tech) \\
$\# 8$ & 46 & 16 & BL & $9 ; 2$ (F) & 3 (high tech, low tech) \\
$\# 9$ & 44 & 12 & BL & $9 ; 11(M)$ & 3 (high tech, low tech) \\
$\# 10$ & 40 & 15 & LD & $5 ; 11(F)$ & 1.6 (high tech, low tech) \\
$\# 11$ & 51 & 12 & BL & $9 ; 0$ (F) & 3 (high tech, low tech) \\
$\# 12$ & 42 & 18 & ASD & $7 ; 5$ (M) & 4 (high tech, low tech) \\
\hline
\end{tabular}

All values are in years.

$A S D=$ autism spectrum disorder; $H I=$ hearing impairment; $B L=$ brain lesions; $I D=$ in tellectual disability; $\mathrm{LD}=$ language disorder.

such as the participants' age and education. The interview topics section was composed with questions appropriate to the purpose of the study after consulting the relevant body of literature, then revised by 2 Ph.D.- track SLPs with more than ten years of clinical experience, including experience in qualitative research and AAC parent education. The questions thus developed were applied to a preliminary interview with a mother of a child with CCN due to cerebral palsy and subsequently reviewed for suitability and acceptability, a few questions being added at this point to finalize the questionnaire. All questions in the interview topics section were composed as semi-structured open questions, as the study sought to explore the individual experiences of parents with regard to AAC intervention in depth (Im \& Park, 2018). Examples of specific questions were as follows. First, general questions such as "What does your child like?" and "What is your child's disposition or personality?" were included in order to ease into the parental interviews and assist with the understanding of their children (Brad, Skinner, Roberts, \& Hennon, 2006). Next were questions related to AAC intervention, such as: "How did you decide upon AAC intervention for your child?"; "How was your experience with AAC intervention?"; "What are the factors that affected your acceptance of AAC?"; "Do you have any wishes with regard to AAC?"; and "What advice would you give to parents who are undecided on or rejecting AAC intervention?". 


\section{Procedures}

Interview data were collected for a period of 4 months, from May to August 2019. As mentioned above, the recommenders introduced parents meeting the prerequisites and the researcher made direct contact with those parents to confirm their intent to participate in the study before determining the date, time, and location of the interview for those parents who agreed. All interviews were conducted face-to-face at a time and place settled at the participant's convenience. The researcher began by reiterating the intent and purpose of the study and the rights of participants before acquiring written consent to participate in the study and to allow the interview to be recorded. Then, an in-depth interview was conducted using semi-structured questions.

The time required for the interviews varied from approximately 1 hour and 30 minutes to 2 hours and 40 minutes depending on the participant. As the researcher proceeded with the transcription and data analysis immediately after the end of each interview even while initiating the next one, the data was supplemented by exchanging emails and text messages with the participants if any matters were incomplete or in need of confirmation. If an additional face-to-face interview was deemed necessary, a follow-up interview was scheduled. Parent interviews were continued until they reached a saturation point where no new information was being added.

\section{Creating transcripts}

The contents of the interviews were recorded on a Samsung Galaxy A7 and later transcribed into Microsoft Word. The recording time related to the research questions varied from 44 to 110 minutes, depending on the participant. The accuracy of the transcription was reviewed by a doctoral student from language pathology brought on as a research assistant to evaluate the correspondence between recording and transcription. The transcription composed in consensus with the reviewer amounted to a total of 363 pages of $A 4$ paper.

The transcription was sent to the individual participants by email for review of the content and their consent for it to be used as is. As a result, most of the participants agreed to the usage of their transcriptions, with the exception of one who responded they had sent an edited version of the file from which certain parts had been removed. This decreased the total length of the transcription by 5 pages, and ultimately a final transcription numbering 358 pages of A4 paper was completed and used as the basis for analysis.

\section{Data analysis}

As this study sought to find the answers to its research questions in the experiences of parents, it took the approach of qualitative research recommended by existing studies (Moorcroft et al., 2019a, 2019b; Pati, Colorafi, \& Evans, 2016). Merriam (2009) stated that data analysis in qualitative research is a process that occurs simultaneously with that of data collection. This study analyzed data using constant comparative method. And as such the researcher attempted to derive concepts through continuous comparison and questioning, and to categorize the collected data (Corbin \& Strauss, 2008).

The researcher first carried out open coding to create codes containing meaningful information from the transcription with the research assistant. In other words, we freely read the transcription separately, highlighting significant phrases, clauses, or sentences judged relevant to the research topic (Park, Kim, Bang, Oh, \& Im, 2016) and thereby identifying and naming concepts to create each temporary codebook. We then read through the transcription line by line, comparing, discussing, and supplementing the codes of each temporary codebook and writing down the agreed-upon code names on colored Post-it notes to complete a synthesized codebook reflecting the consensus between two of us. Next we gathered the coding data of the codebook, i.e., the colored Post-it notes, into one place, rereading and making continuous comparisons to categorize them and thus draw appropriate subthemes and themes from and give headings to it.

Through the abovementioned analytic process, 7 themes and 24 sub-themes related to parents' experiences of AAC intervention for their children were revealed. Additionally, 2 themes were derived regarding the factors affecting the acceptance of AAC intervention for one's children, with 7 associated sub-themes.

\section{Efforts to secure reliability and validity}

This study sought to reduce error in the development of interview topic questions and the processes of data collection and transcription by engaging 2 SLPs and a research assistant in addition to the researcher, in order to minimize the researcher bias. The researcher and the assistant also conducted ongoing peer review to 
secure credibility and validity of coding and theme derivation in the process of analysis of the collected data (Im \& Park, 2018). This study also endeavored to analyze interview data objectively by undergoing a process of member checks, in which participating parents were provided with interview transcriptions by e-mail and their consent confirmed. Finally, the researcher engaged one nonparticipating parent of a child with $\mathrm{CCN}$ to verify whether the results of the study were validated by personal experience, receiving affirmative expressions of "Yes" and "Parent education is of paramount importance." This was a part of our efforts to secure the dependability presented as the evaluative standard for qualitative research by Lincoln \& Guba (1985).

\section{RESULTS}

Analysis of participant interviews revealed 7 themes relevant to parents' experiences of the AAC intervention of their children

Table 2. Themes and sub-themes related to participants' experiences of AAC intervention

\begin{tabular}{|c|c|}
\hline Themes & Sub-themes \\
\hline $\begin{array}{l}\text { Increase in satisfaction } \\
\text { with communication } \\
\text { intervention }\end{array}$ & $\begin{array}{l}\text { Dissatisfaction with conventional therapy approaches } \\
\text { Increase in child's language skills } \\
\text { Decrease in child's problem behaviors } \\
\text { Improvement in child's social skills } \\
\text { Experience of the joys of communication }\end{array}$ \\
\hline $\begin{array}{l}\text { Awareness of need for } \\
\text { early AAC intervention }\end{array}$ & $\begin{array}{l}\text { Importance of trying } A A C \text { intervention } \\
\text { Early initiation of } A A C \text { intervention }\end{array}$ \\
\hline $\begin{array}{l}\text { Change in expectations } \\
\text { for child's quality of life }\end{array}$ & $\begin{array}{l}\text { Identification of child's potential } \\
\text { Hope for independent living } \\
\text { Anticipation of development into true member of society }\end{array}$ \\
\hline $\begin{array}{l}\text { Increase of competence } \\
\text { in parenting }\end{array}$ & $\begin{array}{l}\text { Change in parenting style } \\
\text { Drive to communicate through multimodal means } \\
\text { Recognition of need for self-care } \\
\text { Participation in parenting activities }\end{array}$ \\
\hline $\begin{array}{l}\text { Need for improvement } \\
\text { of AAC systems }\end{array}$ & $\begin{array}{l}\text { Limited nature of symbols } \\
\text { Need for improvement in quality of AAC aids } \\
\text { Need for increase in portability }\end{array}$ \\
\hline $\begin{array}{l}\text { Demand for increased } \\
\text { access to AAC }\end{array}$ & $\begin{array}{l}\text { Need for increase in professional expertise } \\
\text { Need for cooperation among institutions } \\
\text { Need for increase in parent training } \\
\text { Lack of objective information } \\
\text { Request for financial assistance }\end{array}$ \\
\hline $\begin{array}{l}\text { Continued expectations } \\
\text { of speech production }\end{array}$ & $\begin{array}{l}\text { Search for means of forcing speech production } \\
\text { Difficulty in abandoning hopes of speech production }\end{array}$ \\
\hline
\end{tabular}

with $\mathrm{CCN}$, i.e., increase in satisfaction with communication intervention, awareness of need for early AAC intervention, change in expectations for child's quality of life, increase of competence in parenting, need for improvement of AAC systems, demand for increased access to AAC, and continued expectations of speech production, as well as 24 sub-themes all presented below in Table 2. In addition, 2 themes and 7 sub-themes regarding factors affecting the acceptance of AAC intervention were identified, presented in Table 3.

\section{Parents' experiences of AAC intervention} Increase in satisfaction with communication intervention

Parents who participated in the study identified a significant increase in overall satisfaction with their children's communication intervention compared to before AAC intervention. Parents reported experiencing dissatisfaction with conventional therapy approaches, expressing for example "My satisfaction has greatly decreased, by about 30\%” (\#3), "The SLPs changed a lot over the course of the process" (\#6), and "My satisfaction with speech therapy wasn't very high" (\#8). Conversely, parents reported AAC intervention led to an increase in their children's linguistic abilities: their children produced words, enhanced their pronunciation and sentence construction, learned the Korean alphabet, and expressed emotions, among other improvements. Parents articulated their enthusiasm in statements such as "My child used to rely nearly entirely on gestures, but now uses words to communicate everything, even if on a basic level” (\#12), "Although I speak a regional dialect, they pronounce things clearly and accurately according to standard dialect, so I think that's what makes it good" (\#7), "I think it works faster from a place of literacy" (\#9), "My child now expresses emotions in diverse ways, up to "I'm feeling gloomy" (\#11). As

Table 3. Themes and sub-themes related to factors affecting the acceptance of AAC intervention

\begin{tabular}{ll}
\hline Themes & \multicolumn{1}{c}{ Sub-themes } \\
\hline $\begin{array}{l}\text { Parent perception and } \\
\text { propensity }\end{array}$ & $\begin{array}{l}\text { Trust in the recommender } \\
\text { Recognition of child's limitations } \\
\end{array}$ \\
& $\begin{array}{l}\text { Parent's disposition and personality } \\
\text { Awareness of the importance of communication }\end{array}$ \\
Environmental support & $\begin{array}{l}\text { Financial support } \\
\text { Parent education } \\
\end{array}$ \\
& Objective evidence \\
\hline
\end{tabular}


can be seen from quotes such as "From the moment we could communicate, there was a reduction in aggressive, self-harming, and violent behaviors and an improvement in impulse control” (\#1), "Unfamiliar routes used to make my child so irritable... I thought, oh, I can breathe easy now" (\#2), "Social skills are improving, right?" (\#4), parents also experienced a significant decrease in their children's problem behaviors and an increase in their social skills. Above all, parents declared that they were able to discover the joys of communication, stating for example that "Communicating with my child is such a delightful experience, and the more I communicate with my child the more I want to do it” (\#3).

\section{Awareness of need for early AAC intervention}

Parents unanimously professed the importance of trying AAC intervention regardless of doubts, with words such as "I'd like to tell people to just try it. Our kids need to encounter many things. It's important to try. I think that's the most important. To just try it" (\#7). They also recognized the importance of providing early AAC intervention to children with $\mathrm{CCN}$, expressing their regret that they had not started a little sooner when their children were younger.

It would have been better to have started when my child was 3, but we only came across it when she was nearly 7. AAC (aids) keep changing, they get better and more varied and able to go more in-depth $\cdots$ I want to tell other parents to let therapists try communicating with their children. Then they'll also discover 'My child is choosing things and communicating with (their) therapists,' and when they know that they'll tear up, really $\cdots(\# 11)$

If we'd started sooner my child, just sooner, he has a dent in his forehead. He drove his head so hard into the floor it dented his skull and it won't fill back in. There are several places, scars $\cdots$ So I just wonder why I didn't make active use of means like this (\#1).

\section{Change in expectations for child's quality of life}

Parents reported their expectations for their children's lives had been changed by AAC intervention. More specifically, parents were able to recognize their children's potential through AAC in- tervention, as in "I was surprised she knew so many words, because I hadn't taught them to her. She knows so much but I had no idea" (\#11) and "I think my child know more *.. I can see what he knows, in a substantial sense" (\#6), and with expressions such as "The goal is to live without me" (\#7) and "Living her own independent life standing on her own two feet" (\#10) articulated their growing hope for their children to be able to lead independent lives without the need for parental assistance, and the accompanying anticipation of their children's development into "healthy and happy members of society" (\#1).

\section{Increase of competence in parenting}

Parents stated that their children's AAC intervention led them to take initiative in a variety of ways, including altering their parenting style, striving to communicate through multimodal means, recognizing "the need for parents to care for their own selves" (\#5) and organizing parental gatherings or collaborative opportunities with professionals, thus improving their parenting capabilities.

AAC opened the door for me $\cdots$ It gave me the sign that there was a problem with my parenting style $\cdots$ I was completely missing things like autonomy and self-determination. I thought as a mother I should do everything in my child's place $\cdots$ When my child was 7, I invited a special education teacher, a general education teacher, an activity assistant, an AAC teacher, a play therapist, an occupational therapist, and myself to my child's classroom, and the seven of us held a IEP meeting $\cdots$ I took the lead a lot (\#2).

Even special education teachers used to ask me things regarding my child rather than attempt to communicate with my child as if it were only natural, and I didn't question it, either, speaking for my child and occasionally having to answer even though I couldn't tell my child's opinion ‥ These days I say "I' 11 ask her" and I keep trying, keeping in mind that I need to hammer home to myself once more the necessity of asking the person directly involved no matter how small the matter (\#3).

\section{Need for improvement of AAC systems}

Although parents showed relatively positive attitudes toward 
AAC systems, e.g." "I would rate the current AAC devices at about 80 points" (\#5), they also expressed the need to mitigate the limited nature of the symbols, improve the quality of aids (e.g., fixing low voice quality), and enhancing the portability of AAC aids, e.g. "It's a burden to mothers. We have to look after our children while lugging the AAC aids around (\#7).

Another major demand identified was related to graphic symbols, e.g., "The pictures are, shall I say, too hard. A style drawn in lovelier, softer lines, like our own traditional Korean style, seems like it would suit us more." (\#10), "I think there are limitations to the pictures and such representing emotions" (\#2). With regard to the quality of aids, participants revealed an especial desire for programs that can more easily handle message composition in hightech devices, e.g., "The system is too simplistic. The process of forming sentences takes too long" (\#9), "The categories and such aren't very diverse" (\#6), "Each step is too difficult. I wish the system would become easier to use" (\#7).

\section{Demand for increased access to AAC}

Parents expressed the need for the access to AAC to be improved in the process of intervention for their children. More specifically, parents mentioned not only the shortage of AAC experts, e.g., "There are next to no people with expertise" (\#5), but also the lack of understanding among concerned parties, emphasizing the urgency of the need for increased professional expertise, e.g., "The therapist's expertise is insufficient" (\#10), "I think there's a need for AAC education targeting special education teachers" (\#8).

They also expressed their disappointment at the deficiency in cooperation among the institutions responsible for their children's education and therapy, e.g., "We need inter-institutional communication or arrangements" (\#3), "It's so difficult to act as the bridge between therapist and educator, therapist and therapist" (\#10). In particular, participants emphasized the need for AAC parental training, e.g., "Many parents have an AAC tool due to an infocommunications device distribution project, but it's difficult to use. Parents need to know how in order to use them, but there's nowhere to receive parental training" (\#5), suggesting specific solutions such as promotion and awareness improvement, demonstrations of real-life examples, introduction to mentors, and provision of parent training manuals.
Some parents also mentioned the scarcity of information and data related to AAC and hoped for an improvement in parents' access to information through the vitalization of academic research on the subject, e.g., "When I felt uneasy, I did study.. I searched for more $\cdots$ I came to see a lot of AAC $\cdots$ but there wasn't much information available so I combed through the internet" (\#1). As children with $\mathrm{CCN}$ in need of AAC intervention are "often undergoing therapy and education simultaneously" (\#11) and in a variety of ways and thus are subject to a number of financial constraints, parents also hoped for an improvement in economic accessibility through financial assistance in the form of vouchers or insurance.

\section{Continued expectations of speech production}

The majority of parents who participated in this study were maintaining their hopes for their children's speech production and progress. More than half of the parents reported visiting nonverbal centers or trying forced speech production approaches in order to expedite their children's speech production. They also revealed that, despite their positive experiences of AAC intervention, it remained difficult to abandon their hopes for their children's speech, e.g., "Truthfully I'm still undecided, about speech production $\cdots$ because sometimes, when my child is overjoyed, he vocalizes" (\#4), "For starters, speech production. The goal of therapy is speech, after all” (\#7), "They say speech production will happen once the child turns $10 \cdots$ There are mothers who hold onto hope that their children will start speaking even late" (\#11). There were also reports from parents that the effects of AAC intervention had given them realistic hopes for their children's speech, as in "I couldn't even imagine speech production, but it happened. So now we're chasing after speech and setting our focus on it, through AAC” (\#2).

\section{Factors affecting acceptance of $A A C$ intervention}

The factors that influenced parents' acceptance of AAC intervention were analyzed in 2 themes: parent perception and propensity and environmental support (Table 3).

First, 4 sub-themes related to parent perception and propensity were identified: trust in the recommender, recognition of the child' $s$ limitations, the parent's disposition and personality, and awareness of the importance of communication. Taking a closer look at these sub-themes through quotes from parents, e.g., "I met thera- 
pists through the recommendation of an acquaintance, and I had faith in them because I trusted that person" (\#11), "Believing in that person because I trusted the therapist” (\#7), it was reported that the parent's trust in the recommender had a positive influence on their acceptance of AAC. Parents also stated that recognizing their child's limitations, e.g., "as my child did not begin to talk despite forced speech production therapy" (\#10), "when I admitted, 'my child really can't do this, it will only come with a thousand, with ten thousand practices" (\#3), helped them accept AAC systems. Another factor that facilitated acceptance of AAC was the disposition and personality of the parent. In this regard \#2 said "It was my personality. When I believe, I really believe in it and $\cdots$ I'm the type to seek it out so I heard a lecture on AAC and I found the phone number and contacted them first and got evaluated and started right away," and \#1 stated that her "gentle, resolute, constant personality" helped her accept and continue AAC. Finally, most parents emphasized that awareness of the importance of communication was a factor that assisted them in the acceptance of AAC, e.g., "I thought that communication had to be achieved no matter the means" (\#6).

Second, 3 sub-themes related to influence of environmental support were identified: financial support, parent education, and objective evidence. Taking a closer look at these sub-themes through quotes from parents, financial support was the first to be cited as a help in accepting and sustaining AAC intervention for their children, e.g., "I started because I applied for a voucher, it was for a pilot project. I worked on it for 2 years" (\#11). Most parents also expressed that parent education was a great help in understanding and accepting AAC, e.g., "I came to accept it after I heard a lecture by the head of the center. Listening to the parent education made me realize it wasn't what I'd thought it was. So, I dove in" (\#9). Finally, some parents recognized that objective evidence helping parents to understand AAC aided them in accepting AAC intervention, e.g., "There was a lot of temptation'. I read several research papers" (\#1), "I heard there were many cases where verbal expression was aided by PECS. And the papers said the same, so then [I thought], let's try it"(\#12).

I was just opening my eyes to this thing called AAC when I heard they were holding a conference $\cdots$ so I went $\cdots$ Seeing and hearing various things at the conference, I thought 'that seems nice' and that I want to try that with my own child, and I set out to search for an expert (\#5).

\section{CONCLUSION}

This study sought to examine, through one-on-one in-depth interviews of 12 parents of children with $\mathrm{CCN}$ who are receiving AAC intervention services, the key content of their experiences with AAC. It also sought to explore the factors, within parents' practical experiences, that facilitated their acceptance of AAC intervention for their children.

\section{Parents' experiences of their children's AAC intervention}

Drawing from parents' experiences of the AAC interventions for their children with $\mathrm{CCN}$ led to the identification of 7 themes, each with their respective associated sub-themes. The discussions centered on these themes are as follows.

First, parents who started AAC intervention in a state of dissatisfaction with conventional speech and language therapy and reported an increase in their satisfaction regarding communication intervention. Children with $\mathrm{CCN}$ begin communication intervention early on due to their conspicuous communicative problems. However, conventional therapeutic approaches focused on eliminating or reducing the symptoms of the individual's communication disorders (Justice \& Redle, 2013) are often not of significant help to these children. Through AAC intervention, parents experienced, among other things; an increase in their children's language skills, a decrease in their problem behaviors, an improvement in their social skills, and experience of the joys of communication, leading to a significant increase in satisfaction with their interventions. These positive outcomes arising from AAC intervention are similarly mentioned in many preceding research studies (Beukelman \& Mirenda, 2013; Drager et al., 2010; Iacono, 2004; Im \& Park, 2018; Jung \& Han, 2012; Marshall \& Goldbart, 2008).

Second, the parents who participated in this study recognized the importance of early AAC intervention. They articulated that they had realized in particular both the importance of trying AAC and of beginning AAC intervention as early as possible. The importance of early AAC intervention is also a matter on which Cress 
\& Marvin (2003), who emphasized the need to provide AAC options early on by writing lucidly on the 9 questions principally raised by parents, have provided empirical support, along with many other researchers (Beukelman \& Mirenda, 2013; Drager et al., 2010; Romski, Sevcik, Barton-Hulsey, \& Whitmore, 2015; Smith \& Hustad, 2015). Romski et al. (2015) stated based on objective data that it was of paramount importance for family and practitioners to have conviction about providing AAC intervention to very young children. The experiences of the parents who participated in this study were also revealed to corroborate these results.

Third, the parents reported that their hopes for their children to lead independent lives and develop into true members of society had grown as AAC intervention allowed them to identify their children's potential. Parents named the fact that their children had become able to self-determine by making choices one of the most significant merits of AAC intervention, adding that they had come to realize that their children's autonomy and right to self-determination had been completely ignored and that disregard taken for granted until the present. These parental experiences and changes in perception also support the argument made by Drager et al. (2010) that providing AAC intervention to children with CCN can develop their communication skills, raise their levels of social participation, increase their everyday independence in areas such as making choices, and improve their overall quality of life. Systematic and sustained AAC intervention efforts are needed to help children with CCN fulfill their potential as much as possible and develop into independent members of society.

Fourth, the participants in this study experienced a strengthening of their competence as parents. In this regard, parents reported their parenting attitudes underwent a positive change, and that they learned to try for diversification of communication modalities, recognized the necessity of self-care, and started participating in parent activities. They also grew more confident in their parenting as they began to communicate with their children through AAC intervention and the attitudes of their family and acquaintances experienced positive change, and with their newfound understanding of the paramount importance of their own mental welfare as parents to the raising of their children, began to seek opportunities to act collaboratively with other parents for the purpose of self-care. The importance of implementing AAC interven- tion for children with $\mathrm{CCN}$ as a family-oriented process is known (Cress, 2004; Kim \& Park, 2012). In the case of Korea, there is a tendency for mothers to primarily bear the responsibility of care for children with $\mathrm{CCN}$, with fathers recording low rates of participation in childrearing. In order to improve the results of AAC intervention for children with CCN, it is essential to involve not only the children in question but their family, from fathers and mothers to siblings and beyond.

Fifth, the parents acutely realized the need for the improvement of AAC systems. Parents expressed disappointment with the limitations of the symbols and hoped in particular for the diversification of graphic symbols related to emotions. As any deficiency in the vocabulary or the symbol that represent the vocabulary in AAC systems can be a major factor in avoidance of AAC usage or abandonment of the system (Beukelman \& Mirenda, 2013; Shin, 2017a, 2017b), this is an issue in need of urgent address. Parents also observed the need for improvement in the quality of AAC aids, highlighting in particular the low voice quality of high-tech devices and the complexity of message construction, both issues that have been raised for some time (Baxter, Enderby, Evans, \& Judge, 2012; McCall, Markove, Murphy, Moodie, \& Collins, 1997; Moorcroft et al., 2019a, 2019b). Finally, parents called for enhanced portability, declaring that AAC aids must not be another burden. Johnson et al. (2006) have emphasized that continual updates of AAC systems is a factor facilitating long-term usage. As Korean technology has advanced rapidly in recent years and high quality AAC systems with minor improvements continue to be released onto the market, we consider this issue one that will be addressed over time.

Sixth, parents who participated in the study experienced dissatisfaction with the accessibility of AAC. Parents emphasized the deficiency in professional expertise and the need to rectify the same. In this regard, it is necessary to pay attention to the body of research precedent (Moorcroft et al., 2019a; De Bortoli, Arthur-Kelly, Mathisen, \& Balandin, 2014) supporting the argument that a lack of professional expertise and experience regarding AAC poses an obstacle to intervention, and that the accumulation of knowledge and experience is imperative to the continual implementation of AAC intervention. Parents also experienced a significant dearth of inter-institutional cooperation, parent education, and objective 
information; and expressed the need for financial assistance with AAC intervention. In order to solve these problems, we need above all else societal awareness and institutional support. Recently, aid projects providing assistive technology devices for people with disabilities and voucher programs such as AAC devices usage intervention service have been ongoing. In the future, it is expected that such public support for enhancing the accessibility of AAC will be further activated.

Seventh, parents struggled to abandon hopes of speech production for their children with CCN. In this respect many parents had sought out forced speech production approaches, and confessed the difficulty of giving up on speech production even when there was little possibility for natural speech development. Concerns and expectations regarding speech development is a subject long raised by parents of children with CCN (Cress \& Marvin, 2003; Jeon \& Kim, 2014; Kim et al., 2013; Shin \& Lee, 2016). Romski et al. (2015) argued that AAC intervention does not impede speech development but in fact facilitates the development of language and communication skills, emphasizing that these results should be publicized widely beyond the scope of the AAC community. On the other hand, the results of this study demonstrated the need for us to truly understand the expectations about speech production and yearning to hear their children's voices held by parents of children with CCN. We must strive to explore the value of various methods of communication and the meaning of true communication (Jeon \& Kim, 2014).

\section{Parents' acceptance factors of AAC intervention}

The factors that affected parents' acceptance of AAC intervention for their children were categorized into 2 themes, i.e., parent perception and propensity and environmental support, and 7 accompanying sub-themes. The discussions centered on these themes and sub-themes are as follows.

First, Sub-themes related to the parent perception and propensity included trust in the recommender, recognition of the child's limitations, the parent's disposition and personality, and awareness of the importance of communication. The majority of parents who participated in this study received information from parents of their children's peers, their trust facilitating their easy acceptance of AAC intervention, and some of these parents also went on to actively introduce AAC to other parents. This corroborates the research results of Donato, Shane, \& Hemsley (2014), who suggested that backing provided by other parents is decisively important to introducing AAC. In order to promote AAC intervention for children with CCN, we must offer active assistance to the formation and activation of parent networks (Moorcroft et al., 2019a). Parents also reported that recognition of their child's limitations and the importance of communication aided them in the acceptance of AAC intervention. They also spoke on the changes in their views over time, an aspect similar to Moorcroft et al. (2019b)' $s$ findings that parents' views on AAC usage can be affected by the ages and diagnoses of their children. We do not seek to rely on $\mathrm{AAC}$ as an ex post facto solution or final resort after the child with CCN grows older and it is confirmed that conventional speech and language therapy is no longer of help. Rather, it is because we aim to provide AAC systems at an early stage as an option for more active communication intervention, therefore we must take note of these parental experiences. Parents also identified their dispositions and personalities as factors that helped them to accept AAC intervention for their children. They described their personalities and dispositions in terms such as "I'm impatient and if a problem arises I have to solve it.", "I don't give up even if I'm struggling.", "I have an easygoing personality." corroborating the results of Moorcroft et al. (2019b), who quoted parents' self-descriptions such as "really laid back" and "say yes to anything" and reported that the parent's capacity, inclusive of personality and mental health, can affect their acceptance of AAC systems. To ensure parents can accept and successfully implement AAC intervention for their children with CCN, efforts to strengthen parents' competences through careful consideration of and for their personality traits and mental health are required.

Second, Sub-themes related to environmental support included financial assistance, parent education, and objective evidence. The positive effects of financial assistance and parent education on parents' acceptance of AAC intervention for their children have been documented in several studies and literature (Baxter et al., 2012; Beukelman \& Mirenda, 2013; Moorcroft et al., 2019b). It can be seen in the experiences of the parents who participated in this study that financial assistance such as AAC device distribution project, AAC intervention pilot project, and voucher services as- 
sisted parents in their acceptance and sustained implementation of AAC intervention. Improvements in societal awareness and institutional efforts to increase public relief for the costs of AAC intervention are needed. Participants also noted that parent education helped them understand and accept AAC, adding that parent education should be strengthened. These participants mentioned in particular that, although there was a nationwide dissemination of tablet PCs through a distribution project that provided the device to many children with $\mathrm{CCN}$, it is not being appropriately utilized as an AAC system for communication, stressing the need for accompanying parent or guardian training and education. In this regard participants suggested a number of solutions, including an absolute increase in the currently scarce opportunities for parent education, motivating of parents through the introduction of real success stories, mentoring matchups, group activities, and the implementation of intervention sessions where both parent and child participate. The development of parent training manuals and cooperative efforts by professionals to provide systematic education are also necessary. Finally, objective evidence was shown to aid in the acceptance of AAC. Some parents expressed their disappointment with the lack of objective evidence for AAC, reporting that research papers and textbooks stating AAC did not inhibit but in fact aided speech development had led them to accept AAC. There is a need for the continual accumulation and renewal of the empirical evidence parents require, to be accomplished through either the translation and introduction of recent foreign reference materials or the further vitalization of domestic Korean research. We predict that parents will also cooperate enthusiastically in this process as research participants.

This study examined experiences and acceptance factors of AAC intervention through the stories of parents who have provided AAC intervention for their children with $\mathrm{CCN}$ for a certain period, i.e., a minimum of 1 year. In the process of providing their children with AAC intervention, parents overcame various difficulties and the doubts arising from uncertainty to undergo several positive experiences such as recognition of the joys and importance of communication, the growth of their children skills, and the increase in their competency as parents. Additionally, they were able to express their needs and in so doing present concrete directions for stakeholders including SLPs, special education teachers, policy- makers, and program developers to focus their efforts in going forward. This study reconfirmed in particular the dominant and invaluable role parents play from the first stage of accepting AAC intervention for their children, revealing that the most crucial element of successful AAC implementation is, above all, parent education. Efforts to empower parents such as developing parent training manuals and establishing parent networks must be expedited, and opportunities created for them to be able to work with AAC experts to leverage their individual strengths and resources as key stakeholders toward not only rearing their children with CCN, but for the progress of the AAC community as well.

Although not intended to do so, this study engaged only mothers among parents. Additionally, as participants in this study were on the whole highly educated and showed the tendency to actively explore services available for their children, it is difficult to generalize the research results of these participants to the experiences of other parents of children with CCN. Despite the limitations, the significance of this study lies in that it sought to find concrete solutions to promote the early acceptance of AAC intervention for children with CCN by directly exploring the experiences of parents who implemented AAC intervention even in circumstances lacking in societal awareness and institutional aid. Future research exploring the influential factors for parents who initially accepted but later abandoned AAC intervention will also be needed, as those research results will be of help in finding ways to promote the provision of AAC intervention as required to children with CCN. It may also be useful to conduct a survey of needs for AAC parent education. The results of examining the needs of parent education according to the presence or absence of AAC intervention experience would be helpful to the development of level-based parent education programs.

\section{REFERENCES}

Baxter, S., Enderby, P., Evans, P., \& Judge, S. (2012). Barriers and facilitators to the use of high-technology augmentative and alternative communication devices: a systematic review and qualitative synthesis. International Journal of Language and Communication Disorders, 47(2), 115-129.

Beukelman, D. R., \& Mirenda, P. (2013). Augmentative and alternative communication: supporting children and adults with complex communication 
needs (4th ed.). Baltimore: Paul H. Brookes.

Brad, N., Skinner, D., Roberts, \& Hennon, E. (2006). Communication in young children with fragile $\mathrm{x}$ syndrome: a qualitative study of mother's perspectives. American Journal of Speech-Language Pathology, 15(4), 353364.

Cho, H. J., \& Kang, S. K. (2003). A study on the application of augmentative and alternative communication for children with autism. The Korean Journal of East West Mind Science, 6(1), 1-13.

Corbin, J., \& Strauss, A. (2008). Basics of qualitative research: techniques and procedures for developing grounded theory (3rd ed.). Thousan Oaks, CA: Sage.

Cress, C. J. (2004). Augmentative and alternative communication and language: understanding and responding to parents' perspectives. Topics in Language Disorders, 24(1), 51-61.

Cress, C. J., \& Marvin, C. A. (2003). Common questions about AAC services in early intervention. Augmentative and Alternative Communication, 19(4), 254-272.

De Bortoli, T., Arther-Kelly, M., Mathisen, B., \& Balandin, S. (2014). Speechlanguage pathologists' perceptions of implementing communication intervention with students with multiple and severe disabilities. Augmentative and Alternative Communication, 30(1), 55-70.

Donato, C., Shane, H. C., \& Hemsley, B. (2014). Exploring the feasibility of the visual language in autism program for children in an early intervention group setting: views of parents, educators, and health professionals. Developmental Neurorehabilitation, 17(2), 115-124.

Drager, K., Light, J., \& McNaughton, D. (2010). Effects of AAC interventions on communication and language for young children with complex communication needs. Journal of Pediatric Rehabilitation Medicine: An Interdisciplinary Approach, 3(4), 303-310.

Hughes, C. D., Gabel, R. M., Goberman, A. M., \& Hughes, S. (2011). Family experiences of people who stutter. Canadian Journal of Speech-Language Pathology and Audiology, 35(1), 45-55.

Iacono, T. (2004). Patients with disabilities and complex communication needs. Australian Family Physician, 33(8), 585-589.

Im, M. S., \& Park, H. (2018). "Just a minute, please": the experiences of adults using AAC. AAC Research \& Practice, 6(2), 21-44.

Jeon, G., \& Kim, H. (2014). F.G.I. case study on the difficulties and meanings of use of smart device based-AAC for young children with special needs. The Journal of Child Education, 23(3), 81-103.

Johnson, J. M., Inglebret, E., Jones, C., \& Ray, J. (2006). Perspectives of speech language pathologists regarding success versus abandonment of AAC. Augmentative and Alternative Communication, 22(2), 85-99.

Jung, M. C., \& Han, K. I. (2012). The effect of AAC intervention using PDA on the communication and stereotype behavior of a student with nonverbal autism. Journal of Emotional \& Behavioral Disorders, 28(4), 447-471.

Justice, L. M., \& Redlle, E. (2013). Communication sciences and disorders: a clinical evidence-based approach (3rd ed.). Boston: Pearson Education Inc.

Kim, H., Song, K., \& Choi, Y. (2013). The recognition of speech language pathologists on augmentative and alternative communication. The Journal of Special Children Education, 15(4), 285-306.

Kim, J., \& Yun, H. (2015). The effects of AAc intervention in an inclusive education environment on communication behaviors and sentence expression in ASD. The Journal of Special Children Education, 17(1), 293-315.

Kim, K. Y., Park, E. H. (2012). The effect of the family-centered AAC intervention for a child with autism spectrum disorder and his family. Journal of the Korean Association for Persons with Autism, 12(1), 51-72.

Lim, J., Park, E., \& Ku, J. (2013). A study on experiences and needs of potential AAC users' parents regarding AAC intervention services. Special Education Research, 12(3), 309-332.

Lincoln, Y. S., \& Guba, E. G. (1985). Naturalistic inquiry. Beberly Hills, CA: Sage.

Marshall, J., \& Goldbart, J. (2008). 'Communication is everything I think' parenting a child who needs augmentative and alternative communication (AAC). International Journal of Language \& Communication Disorders. 43(1), 77-98.

McCall, F., Markove, I., Murphy, J., Moodie, E., \& Collins, S. (1997). Perspectives on AAc systems by the users and by their communication partners. European Journal of Disorders of Communication, 32(S3), 235-256.

Merriam, S. B. (2009). Qualitative research a guide to design and implementation. San Francisco: Jossey-Bass.

Moorcroft, A., Scarinci, N., \& Meyer, C. (2019a). "I've had a love-hate, I mean mostly hate relationship with these PODD books": parent perceptions of how they and their child contributed to AAC rejection and abandonment. Disability and Rehabilitation: Assistive Technology, 14(1), 1-11.

Moorcroft, A., Scarinci, N., \& Meyer, C. (2019b). Speech pathologist perspectives on the acceptance versus rejection or abandonment of AAC systems for children with complex communication needs. Augmentative and $\mathrm{Al}$ ternative Communication, 35(3), 193-204.

Oh, H. (2018). A case study on parents' awareness and support request for the application of augmentative and alternative communication (AAC) 
for their children with disability. The Korean Society of Education for Hearing-Language Impairments, 9(2), 175-196.

Pae, B. D., \& Chae, S. J. (2017). The effects of communication intervention using My First AAC application on buying goods of students with severe and multiple disabilities. AAC Research \& Practice, 5(2), 91-124.

Park, S. M., Kim, K. S., Bang, K. Y., Oh, Y. H., \& Lim, E. M. (2016). Counseling research course using ground theory approach. Seoul: Hakjisa.

Pati, D., Colorafi, K. J., \& Evans, B. (2016). Qualitative descriptive methods in health science research. HERD: Health Environments Research \& Design Journal, 9(4), 16-25.

Romski, M., Sevcik, R. A., Barton-Hulsey, A., \& Whitmore, A. S. (2015). Early intervention and AAC: what a difference 20 years makes. Augmentative and Alternative Communication, 31(3), 181-202.

Shin, J., \& Lee, S. (2016). Parents' perception on augmentative and alternative communication for students with severe disability. AAC Research \& Prac- tice, 4(2), 1-18

Shin, S. (2017a). Analysis on base forms of high-frequency predicates to develop augmentative and alternative communication systems. Communication Sciences \& Disorders, 22(1), 341-351.

Shin, S. (2017b). Effect of fixed array AAC graphic symbols on sentence construction. Communication Sciences \& Disorders, 22(2), 159-169.

Smith, A. L., \& Hustad, K. C. (2015). AAC and early intervention for children with cerebral palsy: parent perceptions and child risk factors. Augmentative and Alternative Communication, 31(4), 336-350.

Yang, S., \& Han, K. (2019). The effect of adapted picture books reading intervention based on direct instruction and repeated choral reading using augmentative and alternative communication on the reading ability of a student with moderate intellectual disability. The Journal of Special Children Education, 21(2), 73-102. 


\section{국문초록}

\section{복합적인 의사소통 요구를 지닌 아동의 AAC 중재에 대한 부모의 경험 및 수용 요인 탐색 박현주}

가천대학교 특수치료학과

배경 및 목적: 본 연구는 복합적인 의사소통 요구를 지닌 아동의 부모를 대상으로 $\mathrm{AAC}$ 중재 경험을 살펴보고, $\mathrm{AAC}$ 중재 수용에 영향 을 미친 요인을 파악하여, $\mathrm{AAC}$ 중재의 수용과 이행을 촉진할 수 있는 구체적인 방안을 모색하고자 하였다. 방법: 질적 연구 접근법을 사용하였으며, 연구 참여자는 AAC 중재를 1 년 이상 경험한 복합적인 의사소통 요구를 지닌 아동의 부모 12 명이었다. 이들 참여자를 대 상으로 개별 심층 면담을 진행하여 자료를 구성한 후 지속적 비교법을 사용하여 분석하였다. 결과: $\mathrm{AAC}$ 중재에 대한 경험은 의사소통 중재에 대한 만족도 향상, $\mathrm{AAC}$ 조기 개입의 중요성 인식, 자녀의 삶에 대한 기대 변화, 부모 역할의 역량 강화, $\mathrm{AAC}$ 에 대한 접근성 강화 요구, $\mathrm{AAC}$ 체계 개선의 필요성, 말에 대한 멈추지 않는 기대 등 7 개의 주제와 그에 따른 24 개의 하위 주제가 도출되었다. $\mathrm{AAC}$ 중재 수용 에 영향을 미친 요인은 부모 인식 및 성향과 환경적 지원이라는2개의 주제와 그에 따른 7 개의 하위 주제가 도출되었다. 논의 및 결론: 연 구 결과를 토대로 복합적인 의사소통 요구를 지닌 아동의 AAC 중재에 대한 수용 및 지속적인 이행을 위해 고려해야 할 요인과 지원 방 안을 논의하였다. 복합적인 의사소통 요구를 지닌 아동의 AAC 중재를 더욱 활성화하기 위해서는 이해관계자들의 지속적인 협력과 노 력이 요구된다.

핵심어: 보완대체의사소통, 복합적인 의사소통 요구를 지닌 아동, AAC 중재, 수용 요인, 질적 연구

\section{참고문헌}

김경양, 박은혜(2012). 가족-중심 보완대체의사소통(AAC) 중재가 자폐범주성 장애아동의 의사소통 능력과 가족 인식에 미치는 영향. 자폐성장애연 구, 12(1), 51-72.

김정연, 윤형준(2015). 통합환경에서 AAC중재가 자폐성장애 학생의 의사소통 행동과 문장표현에 미치는 영향. 특수아동교육연구, 17(1), 293-315. 김혜영, 송기범, 최양규(2013). 보완대체의사소통에 대한 언어치료사들의 인식도 조사. 특수아동교육연구, 15(4), 285-306.

박승민, 김광수, 방기연, 오영희, 임은미(2016). 근거이론 접근을 활용한상담연구과정. 서울: 학지사.

배병덕, 채수정(2017). My First AAC앱을 활용한 중재가 중도 중복장애학생의 물건사기 의사소통행동에 미치는 효과. 보완대체의사소통연구, 5(2), 91-124.

신상은(2017a). AAC체계 구축을 위한 고빈도 용언의 기본형 분석. Communication Sciences \& Disorders, 22(1), 341-351.

신상은(2017b). 고정배열된 AAC그림상징이 문장구성에 미치는 효과. Communication Sciences \& Disorders, 22(2), 159-169.

신정미, 이수향(2016). 보완대체의사소통(AAC)에 대한 중도장애 학생 부모의 인식 조사. 보완대체의사소통연구, 4(2), 1-18.

양성빈, 한경임(2019). 직접교수법과 반복 읽기에 의한 보완대체 의사소통 활용수정된 그림책 읽기 중재가 중등도 지적장애 학생의 읽기 능력에 미치 는 효과. 특수아동교육연구, 21(2), 73-102.

오혜정(2018). 장애자녀의 보완 대체의사소통(AAC) 활용에 대한 부모의 인식 및 지원요구에 관한 사례연구. 한국청각언어장애교육연구, 9(2), 175196.

임명순, 박현주(2018) “조금만 기다려주세요": 성인 보완대체의사소통(AAC) 사용자의 경험. 보완대체의사소통연구, 6(2), 21-44.

임장현, 박은혜, 구정아(2013). 보완대체의사소통(AAC) 중재 서비스에 대한 발달장애인 부모의 요구분석. 특수교육, 12(3), 309-332.

전가일, 김호현(2014). 장애 영유아용 스마트 디바이스 $\mathrm{AAC}$ 앱 사용경험을 통한 AAC 사용의 어려움과 그 의미에 관한 초점집단(F.G.I) 사례 연구. 아

동교육, 23(3), 81-103.

정명철, 한경임(2012). 비구어 자폐성장애 학생의 의사소통과 상동행동에 대한 PDA활용 보완 · 대체의사소통 중재의 효과. 정서 - 행동장애연구, 
28(4), 447-471.

조홍중, 강수균(2003). 자폐아동을 위한 보완· 대체의사소통체계의 적용에 대한 인식조사. 한국동서정신과학회지, 6(1), 1-13.

\section{ORCID}

박현주(제1저자, 교신저자, 교수 https://orcid.org/0000-0002-3868-6381) 